\title{
Study of the effect of fuel temperature on gas turbine performance
}

\author{
George Marin ${ }^{1,2}$, Dmitrii Mendeleev ${ }^{1,2, *}$, Boris Osipov $^{1}$ and Azat Akhmetshin ${ }^{1}$ \\ ${ }^{1}$ Kazan State Power Engineering University, 420034, Krasnoselskaya St., 51, Kazan, Russian Federation; \\ ${ }^{2}$ JSC "Tatenergo" branch "Kazan CHP-2", 420036, Tatsevskaya St., 11, Kazan, Russian Federation
}

\begin{abstract}
The development of gas turbine technologies requires the search for new solutions to improve the efficiency of gas turbine plants. The energy characteristics of a gas turbine depend on many external factors the temperature and pressure of the surrounding air including the composition of the fuel gas. This paper considers the effect of fuel gas temperature. Natural gas, synthesis gas, and aviation kerosene are considered as fuel for a gas turbine. For research, a gas turbine of the GE 6FA model was selected and its mathematical model was created. The results of calculations of the effect of fuel temperature on the energy and economic characteristics of a gas turbine are presented. The dependences of the main characteristics of the turbine were obtained. At the same time, the turbine power is assumed constant since during possible operation as part of a combined cycle gas turbine unit it is necessary to maintain a constant temperature of the exhaust gases after the gas turbine. The assumption was made - the costs of heating the fuel were not considered.
\end{abstract}

\section{Introduction}

Currently, widespread modernization of thermal power plants with gas turbine units. Gas turbines are used when upgrading or replacing used equipment. Nevertheless, at the same time, a lot of research is devoted to studying the work and increasing the efficiency of gas turbine plants. There are many ways to increase the efficiency of the gas turbine cycle and reduce fuel consumption for electricity generation. [1-3]

For example, such methods include:

1. Cascade air-cooling in the compressor.

2. The increase in gas temperature in the combustion chamber.

3. The use of supplying an additional working fluid to the flow part.

In this paper, as an alternative to the above methods, fuel heating is considered before it is fed into the combustion chamber of a gas turbine. Fuel heating can be carried out using the heat of the exhaust gases of the turbine itself. If a gas turbine operates as part of a combined cycle gas turbine unit it can be used to heat steam from steam turbine offsets. [4-6].

\section{Materials and methods}

The article describes an example of a gas-turbine unit (GTU) of PG6111FA type (from "GE Energy"). The main characteristics of the gas turbine installation are presented in table 1 .

During GTU operation, filtered atmospheric air passes through the inlet mixing air chamber assembly and then is compressed in an 18-speed axial compressor. Compressed air from the compressor enters the annular space surrounding the six combustion chambers then the air enters the space between the outer casing and the inner lining of the combustion chambers and enters the combustion zone through the metering holes in the lining of each combustion chamber. Fuel injectors supply fuel to each of the six combustion chambers in which the fuel mixes with air and inflames. The hot gases from the combustion chambers expanding enter six separate transition compartments attached to the discharge side of the inner lining of the combustion chambers and then to the section of the three-stage turbine. Each stage consists of a series of fixed nozzle devices behind which a number of turbine blades is located. In each row of nozzle devices the kinetic energy of the jet increases that is accompanied by a corresponding pressure drop and in each subsequent row of rotating blades, part of the kinetic energy of the jet is spent on the useful work of the turbine rotor. After the passage of the blades of the third stage, the exhaust gases are sent to the exhaust housing and the diffuser. Then the gases are sent to the waste-heat recovery boiler. The resulting rotation of the shaft leads through the reduction gear to the rotation of the generator rotor which converts it into electrical energy. [6-10]

\footnotetext{
* Corresponding author: dylankn@ya.ru
} 
Table 1. Technical characteristics of a GTU (PG6111FA).

\begin{tabular}{|c|c|c|c|}
\hline No & Characteristic & $\begin{array}{c}\text { Meas. } \\
\text { unit }\end{array}$ & Value \\
\hline 1 & $\begin{array}{c}\text { Power at the generator } \\
\text { terminals }\end{array}$ & $\mathrm{kW}$ & 80000 \\
\hline 2 & Atmospheric pressure & $\mathrm{kgf} / \mathrm{cm}^{2}$ & 1.013 \\
\hline 3 & $\begin{array}{c}\text { Compressor inlet } \\
\text { temperature }\end{array}$ & ${ }^{\circ} \mathrm{C}$ & 15 \\
\hline 4 & $\begin{array}{c}\text { Relative humidity at the } \\
\text { compressor inlet }\end{array}$ & $\%$ & 60 \\
\hline 5 & $\begin{array}{c}\text { The pressure of the fuel } \\
\text { before the gas module }\end{array}$ & $\mathrm{kgf} / \mathrm{cm}^{2}$ & $25.9-30.8$ \\
\hline 6 & $\begin{array}{c}\text { The number of stages in the } \\
\text { compressor }\end{array}$ & $\mathrm{pcs}$ & 18 \\
\hline 7 & $\begin{array}{c}\text { The number of steps in the } \\
\text { turbine }\end{array}$ & $\mathrm{pcs}$ & 3 \\
\hline 8 & Air flow & $\mathrm{m}^{3} / \mathrm{s}$ & 166 \\
\hline 9 & $\begin{array}{c}\text { Compression ratio } \\
\text { compressor }\end{array}$ & ${ }^{\circ} \mathrm{C}$ & 385 \\
\hline 10 & $\begin{array}{c}\text { Air temperature after the } \\
\text { comprem }\end{array}$ & ${ }^{\circ} \mathrm{C}$ & 603 \\
\hline 11 & Flue gas temperature & ${ }^{\circ} \mathrm{C}$ & 1325 \\
\hline 12 & $\begin{array}{c}\text { The temperature of the } \\
\text { gases after the combustion } \\
\text { chamber }\end{array}$ & & \\
\hline
\end{tabular}

The low $\mathrm{NO}_{\mathrm{x}} 2.6$ (DLN 2.6) nitrogen fuel combustion system controls the distribution of fuel supplied to the multi-nozzle pre-mixers and reduces $\mathrm{NO}_{\mathrm{x}}$ levels in the exhaust without the need for water or water vapor to be added to the fuel gas. The distribution of fuel flow in each assembly unit of fuel injectors is calculated to maintain the load of the unit and the distribution of fuel to ensure optimal turbine emissions.

The combustion system with a counter flow includes six combustion chambers located on the periphery of the compressor discharge housing. The combustion chambers are numbered counterclockwise when viewed from the top of the machine in the discharge direction. This system also includes fuel injectors, a spark plug system, flame control sensors and cross-ignition tubes.
Hot gases formed during the combustion of fuel in the combustion chambers pass through the transition compartments with forced cooling to the turbine.

High-pressure air from the compressor discharge housing is guided around the transition compartments. Part of the air enters the openings in the forced cooling sleeve to cool the transition compartments and is sent to the flow sleeve. The remaining air enters the space between the flow sleeve and the lining of the combustion chamber through the holes in the far end of the flow sleeve in the direction of flow. This air enters the combustion zone through the metering holes to ensure proper combustion of the fuel and through the grooves for cooling the skin of the combustion chamber. Air enters the combustion chamber through six nozzles that disperse the fuel and mix it with the appropriate amount of air supplied to the combustion chamber.

Natural gas, synthesis gas, and aviation kerosene are considered as fuel in this study. For research, the conditional formula for each type of fuel is calculated (table 2).

Table 2. The composition of the conditional formula for the studied fuels.

\begin{tabular}{|c|c|c|c|}
\hline & Natural gas & Gas synthesis & Kerosene \\
\hline Enthalpy & -4483.583 & -2915.0 & -2815.0 \\
\hline Carbon $(\mathrm{C})$ & 6.040 & 7.0726833 & 7.0768 \\
\hline Hydrogen $(\mathrm{H})$ & 22.99232 & 14.932036 & 14.6788 \\
\hline Nitrogen $(\mathrm{N})$ & 0.241048 & - & - \\
\hline Oxygen $(\mathrm{O})$ & 0.05642 & - & - \\
\hline Sulfur $(\mathrm{S})$ & - & - & 0.013595 \\
\hline
\end{tabular}

The functional diagram of the mathematical model is presented in figure 1. Selection window for elements for design scheme is presented in figure 2. For the study, a mathematical model of a gas turbine engine was created in the software package "Automated System of Gasdynamic Research of Energy Turbomachines» (AS GRET).

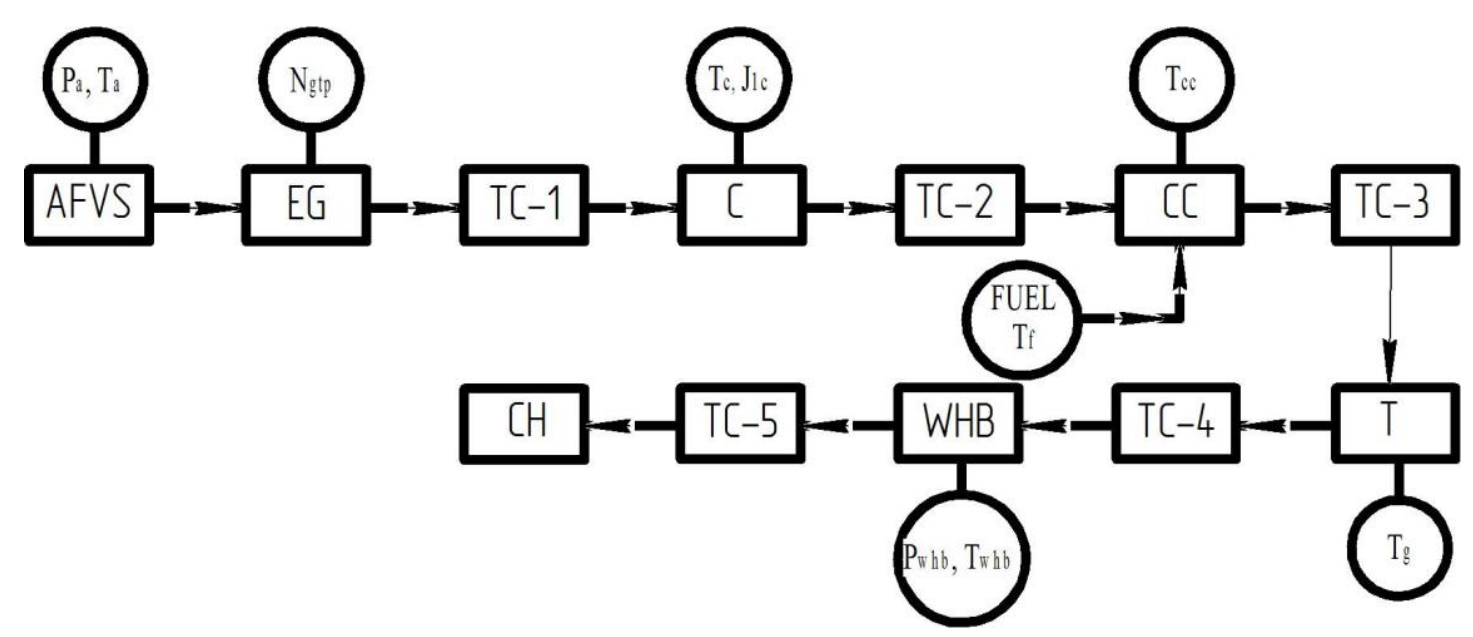

Fig. 1. The functional diagram of the mathematical model (AFVS - an air filtering and conditioning system; EG - an electric generator; TC -1 - a transition channel between AFVS and compressor; $\mathrm{C}-\mathrm{a}$ compressor; TC- 2 - a transition channel between the compressor and the combustion chamber; CC - a combustion chamber; TC-3 - a transition channel between the combustion chamber and the turbine; T - a turbine; TC- - a transition channel between the turbine and the boiler utilizer; WHRB - a waste heat recovery boiler; TC-5 - a transition channel between the waste-heat boiler and the chimney; $\mathrm{CH}$ - a chimney). 
The source data in this study:

Gas turbine power: $77 \mathrm{MW}$

Air temperature: $\mathrm{T}_{\mathrm{a}}=+15{ }^{0} \mathrm{C}$,

Compressor inlet pressure: $\mathrm{P}_{\mathrm{a}}=101.3 \mathrm{kPa}$,

Humidity: $65 \%$.

To assess the effectiveness of the influence of fuel, the following ranges of fuel heating were selected:

For fuel gas from $3{ }^{0} \mathrm{C}$ to $450{ }^{\circ} \mathrm{C}$. The lower limit is defined at $3{ }^{\circ} \mathrm{C}$ since condensation of hydrocarbons and moisture in the fuel gas is possible at a lower temperature which may affect the operation of the fuel injectors. At $3{ }^{\circ} \mathrm{C}$ the absence of liquid in the feed gas is guaranteed. The maximum gas temperature of $450{ }^{\circ} \mathrm{C}$ is because decomposition of natural gas is possible at higher temperatures. [3, 11-14]

Synthesis gas is supplied in the range from $3{ }^{0} \mathrm{C}$ to $350{ }^{\circ} \mathrm{C}$. (The conditions for choosing this range are the same as for fuel gas) [3]

The maximum temperature of aviation kerosene is 65 ${ }^{0} \mathrm{C}$. The fact that the flash point of kerosene is from +28 to $+72{ }^{0} \mathrm{C}$ (the lowest temperature of volatile condensed matter at which the vapor above the surface of the substance is able to flash in the air under the influence of an ignition source, however, is stable after removal of the ignition source does not occur). [15-17].

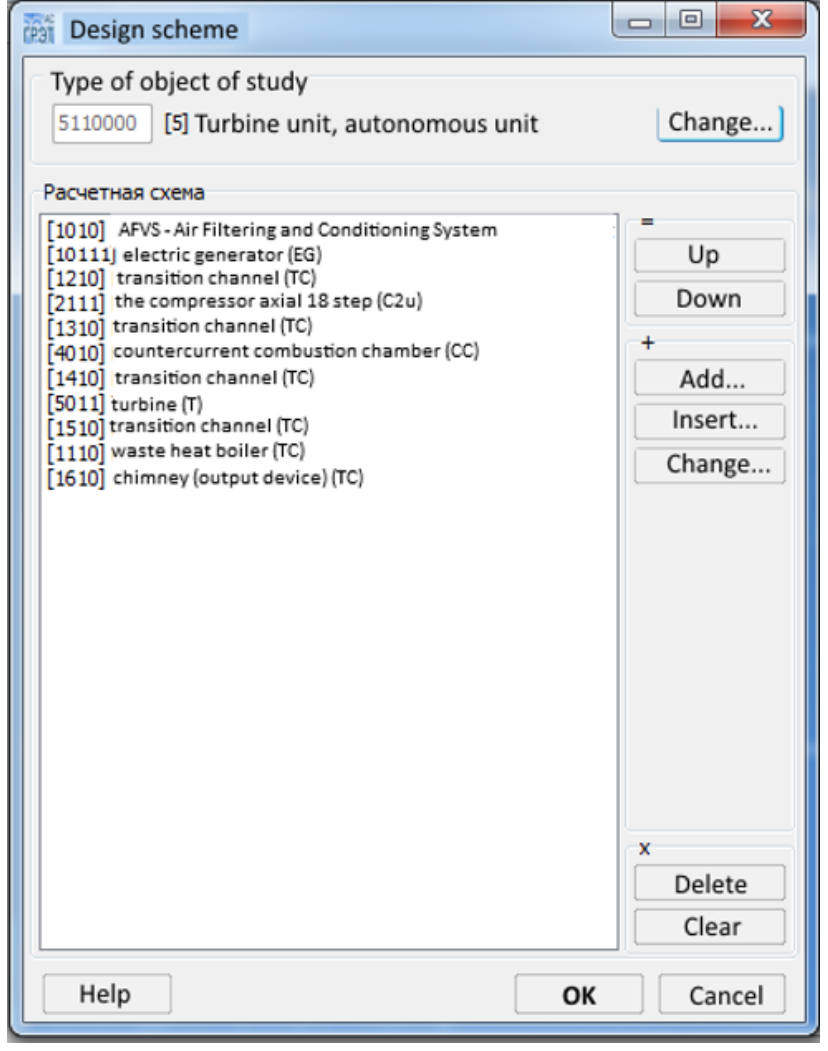

Fig. 2. Selection window for elements for design scheme.

\section{Results and Discussion}

When modeling such complex energy systems as a gas turbine engine, problems arise in setting parameters in

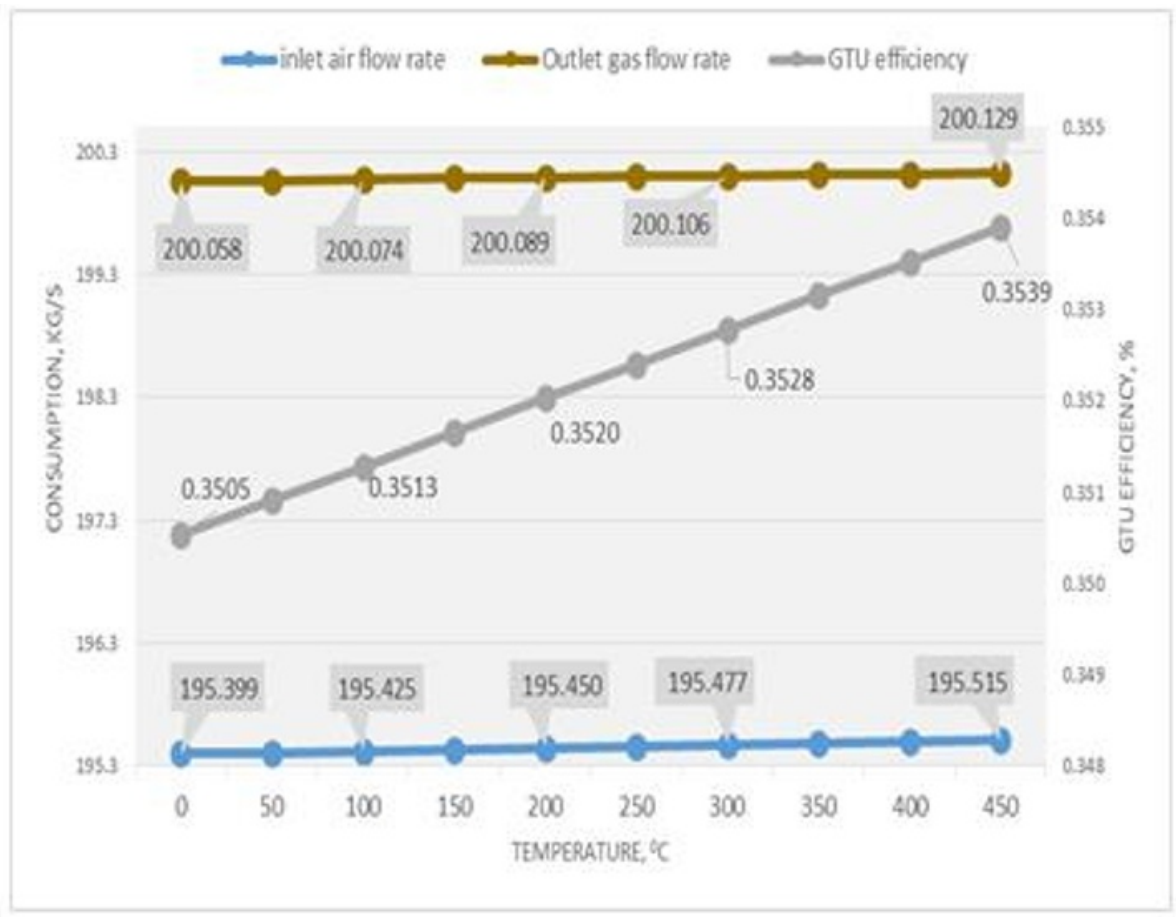

Fig. 3. The dependence of the airflow rate at the inlet and gas flow rate at the outlet of the gas turbine and the efficiency of the gas turbine from the temperature of natural gas 


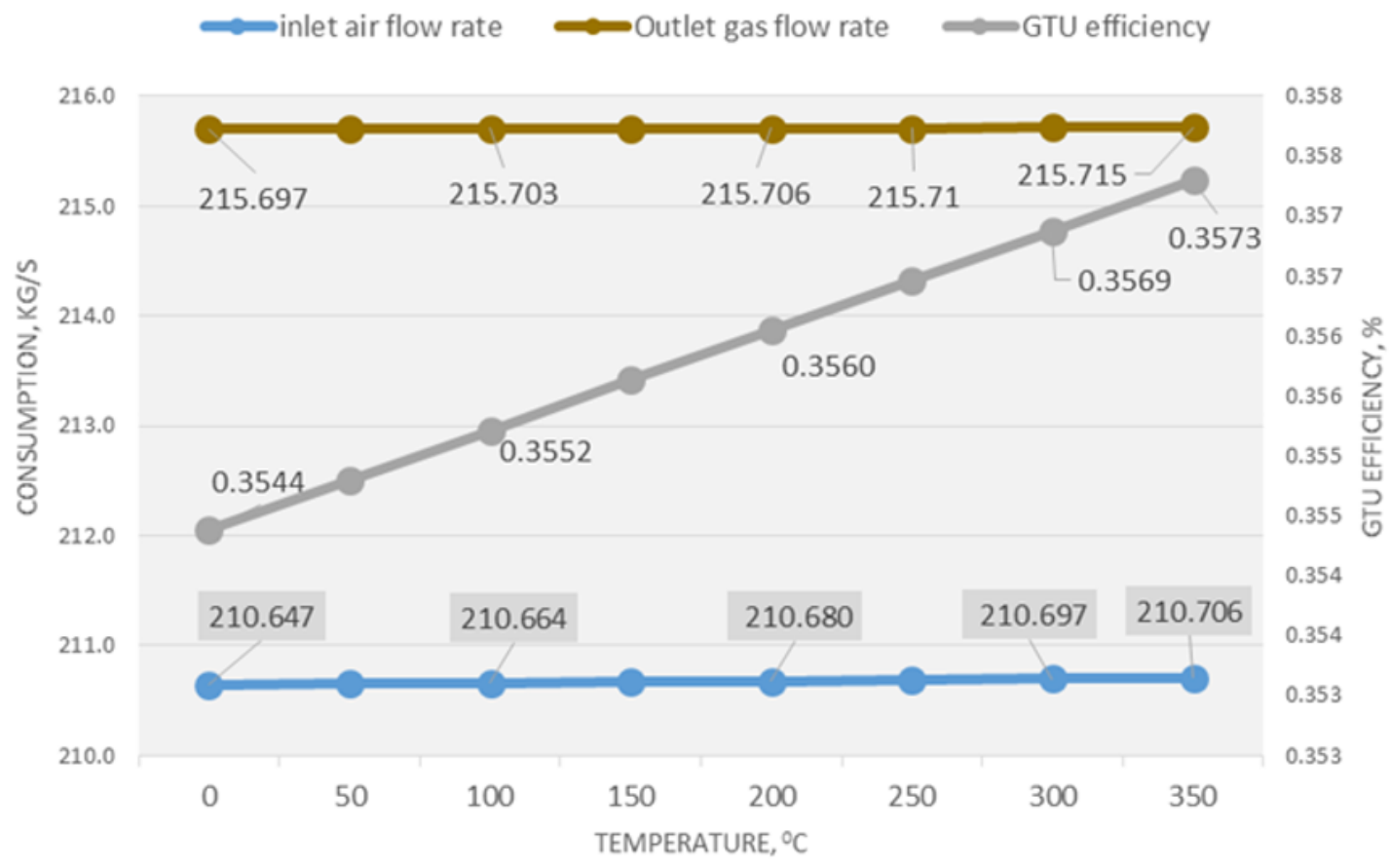

Fig. 4. The dependence of the airflow rate at the inlet and gas flow rate at the outlet of the gas turbine and the efficiency of the gas turbine from the temperature of the synthetic gas.

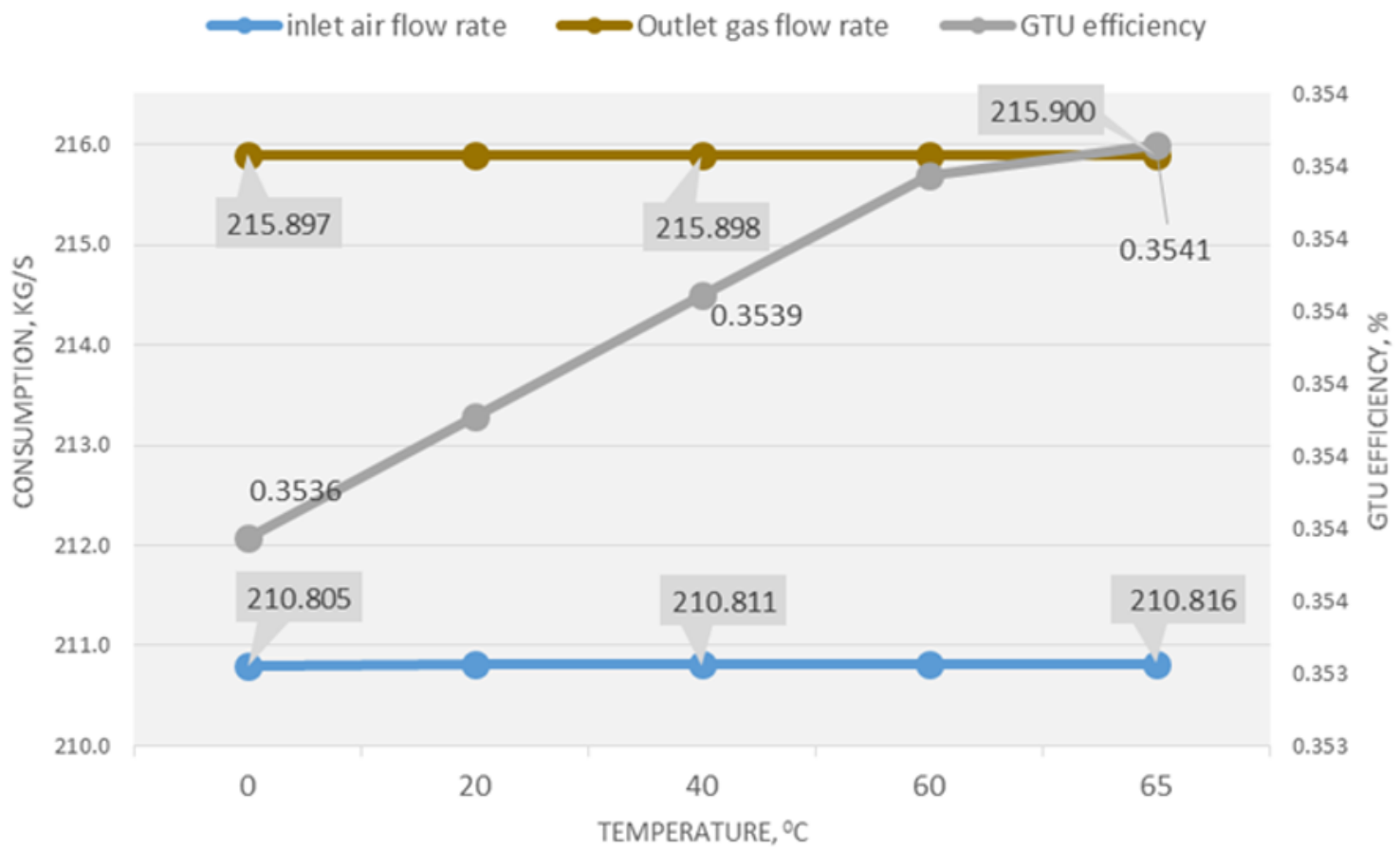

Fig. 5. The dependence of the airflow rate at the inlet and gas flow rate at the outlet of the gas turbine and the efficiency of the gas turbine from the temperature of kerosene.

the zeroth approximation, since the exact value will be determined only after the calculations are completed. To solve this problem, in this study, the method of residual systems is used. [18-20]

The simulation results are presented as graphical dependencies in Figures 3-6.

\section{Conclusion}

In this paper, we consider how gas temperature affects the parameters of a gas turbine plant. In particular, the following elements were noted: 


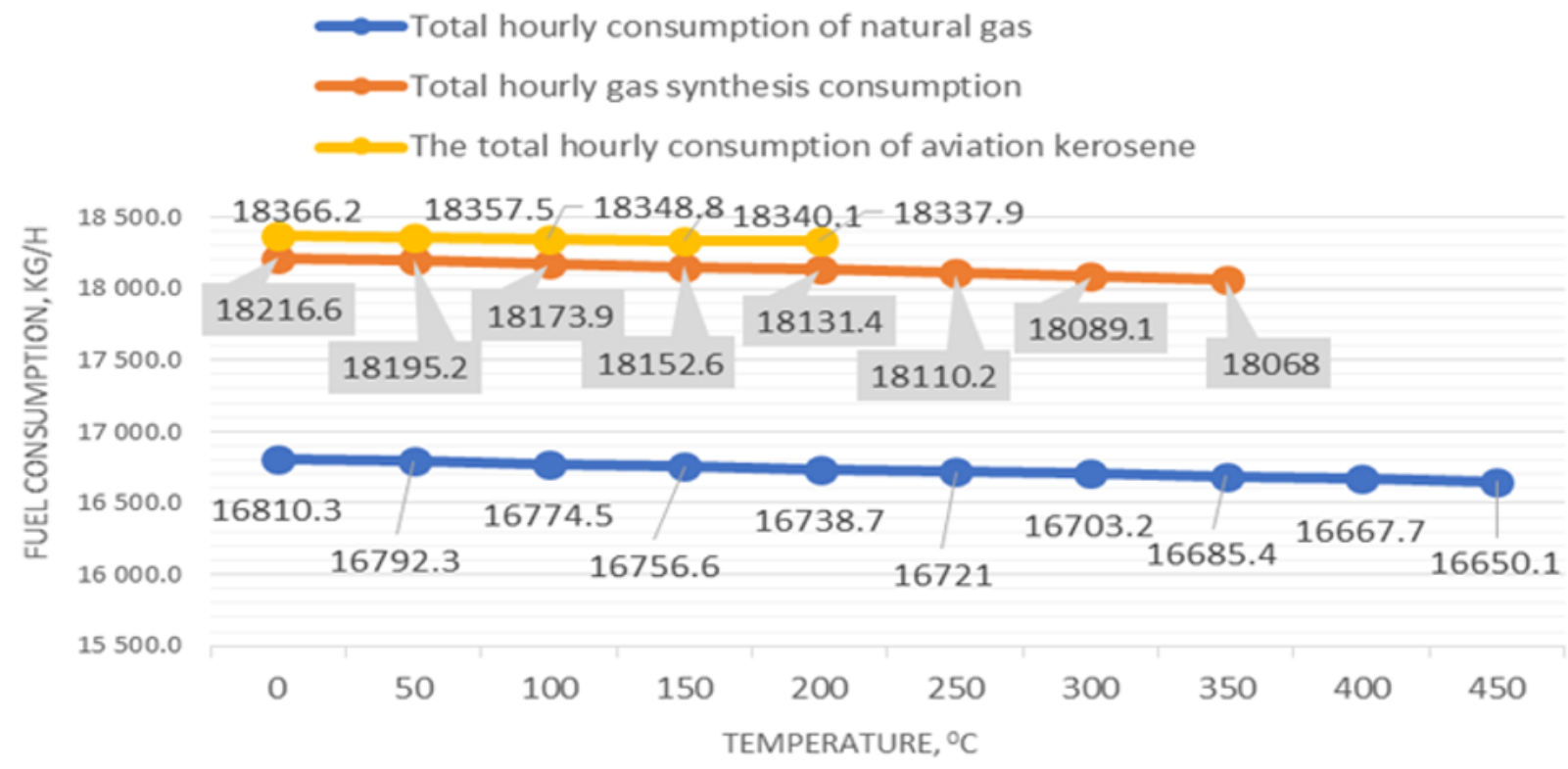

Fig. 6. The dependence of the total hourly consumption of the studied fuels on their temperature.

1. Fuel heating affects the efficiency of a gas turbine installation. When using natural gas, the increase in efficiency was from 35.05 to $35.39 \%$. When working on syngas, the efficiency increase was from 35.44 to $35.73 \%$. When working on aviation kerosene, the efficiency increase from 35.36 to $35.41 \%$.

2. There is a decrease in consumption for each fuel when heating fuel; however, fuel gas is significantly less than for other types of fuel. Given that, gas turbines operate about 8000 hours per year fuel savings when using natural gas (when comparing fuels) can be about 11000 tons. The natural gas savings from heating will be 1280 tons. However, it is worth considering technical issues - how to carry out fuel heating. The costs of this modernization can be comparable with the savings from fuel costs, so it is necessary to conduct research in this direction and look for compromises in various ways.

\section{References}

[1] O.O. Badran, Appl. Energy (1999)

[2] M. Basha, S.M. Shaahid, L. Al-Hadhrami, Energy Procedia (2012)

[3] G.E. Marin, D.I. Mendeleev, A.R. Akhmetshin, 2019 Int. Multi-Conference Ind. Eng. Mod. Technol. FarEastCon 2019 (2019)

[4] E. Bocci, M. Sisinni, M. Moneti, L. Vecchione, A. Di Carlo, M. Villarini, Energy Procedia (2014)

[5] T.A. Clifford, S. Cruz-Manzo, Y. Zhang, V. Panov, A. Latimer, Proc. IECON 2017 - 43rd Annu. Conf. IEEE Ind. Electron. Soc. (2017)

[6] L. Esclapez, P.C. Ma, E. Mayhew, R. Xu, S. Stouffer, T. Lee, H. Wang, M. Ihme, Combust. Flame (2017)
[7] L. Esclapez, P.C. Ma, E. Mayhew, R. Xu, S. Stouffer, T. Lee, H. Wang, M. Ihme, Combust. Flame (2017)

[8] E. Gracheva, A. Alimova, Proc. - 2019 Int. Russ. Autom. Conf. RusAutoCon 2019 (2019)

[9] E. Gracheva, A. Alimova, Proc. - 2019 Int. Ural Conf. Electr. Power Eng. Ural. 2019 (2019)

[10] M. Henke, J. Kallo, K.A. Friedrich, W.G. Bessler, Fuel Cells (2011)

[11] J.G. Kiernan, A.D. Foster, D.T. Harden, Power Eng. (Barrington, Illinois) (1978)

[12] J. Kotowicz, M. Job, M. Brzeczek, Energy (2015)

[13] M.C. Lee, S. Bin Seo, J.H. Chung, S.M. Kim, Y.J. Joo, D.H. Ahn, Fuel (2010)

[14] A.H. Lefebvre, J.H. Whitelaw, Int. J. Heat Fluid Flow (1984)

[15] K. Liu, S. Sadasivuni, N. Parsania, Fuel (2019)

[16] W.E. Bill Forsthoffer, Forsthoffer's Rotating Equip: Handbooks (2005)

[17] M.M. Rahman, T.K. Ibrahim, A.N. Abdalla, Int. J. Phys. Sci. (2011)

[18] D. Rochelle, H. Najafi, Renew. Sustain. Energy Rev. (2019)

[19] P. Weiland, Appl. Microbiol. Biotechnol. (2010)

[20] L. Zheng, J. Cronly, E. Ubogu, I. Ahmed, Y. Zhang, B. Khandelwal, Appl. Energy (2019) 